
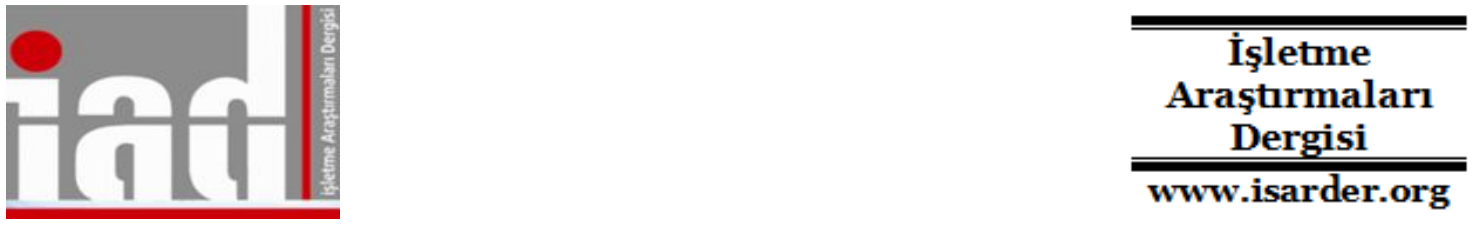

\title{
Self-congruity Influence on Tourist Behavior: Repeat Visitors versus \\ Non-Visitors and First-Time Visitors
}

\author{
M. Mithat ÜNER \\ Gazi University, \\ Faculty of Economics and \\ Administrative Sciences, \\ Ankara, Turkey \\ mithatuner@gazi.edu.tr
}

\author{
Can ARMUTLU \\ Başkent University, \\ Faculty of Commerce, \\ Ankara, Turkey \\ carmutlu@,baskent.edu.tr
}

\author{
Evren GÜÇER \\ Gazi University, \\ Faculty of Tourism, \\ Ankara, Turkey \\ evrengucer@gazi.edu.tr
}

\begin{abstract}
This study investigates the role of prior experience on the impact of actual self and ideal self-congruity on tourists' intention to visit Turkey for leisure purposes. The study draws from an empirical study with 648 subjects conducted in cooperation with the Turkish Ministry of Culture and Tourism. Results suggest that the effect of actual selfcongruity on intention to visit differs according to different levels of tourist experience. While self-congruity has a positive effect on intention to visit for the non-visitors and first-time visitors -- implying that the relationship between self-congruity and intention does not vary between non-visitors and first-time visitors -- this effect loses its significance for repeat visitors. These findings partially support the previous proposed moderating role of prior experience on the impact of self congruity on intention to visit a destination and expand the discussion on this topic raising new questions.
\end{abstract}

Key Words: destination image, self-concept, self-congruity, travel behavior, Turkey.

\section{Introduction}

The literature addressing travel behavior discusses many factors as determinants of tourist behavior. One of the factors and an interesting research topic in tourism literature is destination image. Some scholars measure destination image in various geographical levels like country, region or city (Baloğlu 2001; Baloğlu \& Mangaloğlu 2001; Chaudhary 2000; Chen 2001; Chen \& Kerstetter 1999; Sharaiha \& Collins 1992; Hsu, Wolfe \& Kang 2004;) other researchers study on the influences of image on tourist behavior (Baloglu \& Brinberg 1997; Bramwell \& Rawding 1996; Chen \& Hsu 2000; Chen \& Kerstetter 1999; Dann 1996; Fakeye \& Crompton 1991; Fridgen 1987; Gartner 1993). The studies showing the significance of destination image on tourist behavior 
emphasize the symbolic nature of tourism consumption. In consumer behavior literature, symbolic nature of consumption is first suggested by Levy (1959) stating that consumers do not buy products only for their functionality but also for their meanings associated with symbols. In other words they are consuming the images.

The symbolic nature of consumption and self-congruity and its effect on consumer behavior have been studied empirically over the past five decades. These studies show that consumer behavior is affected by their self-concept, indicating that consumers have more favorable attitudes and more likely to consume products that have images consistent with their self-concept (Belk, 1988; Graeff, 1996; Grubb \& Grathwohl, 1967; Grubb \& Hubb, 1968; Kassarjian, 1971; Landon, 1974; Lee, 1990; Munson and Spivey, 1980; Onkvisit \& Shaw, 1987; Sirgy, 1982; 1985; Solomon, 1983). The stepped-up interest in self-concept research in consumer behavior literature parallels the growing acceptance of an alternative view to the information-processing paradigm (Morgan, 1993). Information processing paradigm borrowed by marketing scholars from cognitive psychology -- in order to understand human thinking and perception using a man-machine analogy (Hackley, 2003:164) -- has been criticized as inadequate to explore important issues in consumer behavior (Hirschman and Holbrook, 1982). This rational assumption neglects the symbolic character of human understanding (Hackley, 2003:164). Belk (1988) describes this shift, as a move away from the consumer as a programmed brain to recognition of the consumer as a human being (Morgan, 1993). This perspective makes consumption central to the meaningful practice of our everyday life -- we consume things that hold particular symbolic meanings and that not only satisfy our needs but also to carry out our self-creation project-- (Wattanasuwan, 2005).

Although in the tourism literature destination image has received considerable attention, there are relatively few studies (Chon, 1992; Hung \&Petric 2012; Kastenholz, 2004; Litvin \& Goh, 2002; 2003; Sirgy \& Su, 2000, Usakli \& Baloglu 2011) on self image and destination image congruity and its effects on tourist behavior. The literature about self-congruity in tourism highlights two important issues. One is about the moderating variables between self- congruity and tourist behavior. The other one is about the measurement. After the conceptual study of Sirgy and Su (2000) that proposes a detailed model with moderating variables such as experience, knowledge and involvement, there is one empirical study testing the moderating effect of experience and involvement between self-congruity and destination choice (Beerli et.al. 2007). On the other hand basically, there are two measurement methods; one is using adjectives called the traditional method, the other one is using statements directly measuring the congruity, called the direct method. Beerli et.al, (2007) uses traditional method in their study. However studies in tourism about self-congruity show that using different methods reveal different results (Litvin \& Goh, 2002). The limited studies about selfcongruity fail to give a fulfilling answer to the question "is it a valid theory in tourism?" Obviously, there is still a need for empirical studies in that research area. This study aims to examine the role of prior experience in the relationship between actual and ideal self-congruity on tourist's intention to visit a destination. In this manner direct method is used to measure self-congruity, and prior experience is categorized differently as nonvisitors, first-time and experienced visitors in order to point out the differences according to varying levels of tourists' experience. According to the purpose of the study Turkey is chosen as a destination because, Turkey is not only one of the most 
important tourism destinations for leisure purposes but also an emerging destination in European tourism.

\section{The Self-Congruity Theory and Hypotheses}

The symbolic nature of products, person object relations and the meaning of objects and consumption have been interesting research areas in sociology and anthropology for years. Researches in psychology show that one's self-concept is a partial determinant of human behavior. Therefore, self-concept is a promising area for consumer research (Grubb \& Grathwohl, 1967). Previous studies in consumer behavior strongly support the idea that self-concept has an important role in determining and understanding consumer behavior (Belk, 1988; Grubb \& Grathwohl, 1967; Grubb \& Hubb, 1968; Kassarjian, 1971; Landon, 1974; Lee, 1990; Munson and Spivey, 1980; Sirgy, 1982; Solomon, 1983). However, the conceptualization of self-concept in the consumer behavior literature is confusing. This is the reason for numerous definitions and conceptualizations of self-concept in the psychology literature (Sirgy \& Su, 2000). There are numerous paradigms with different assumptions in psychology about selfconcept (Reed II, 2002). While Markus and Nurius, (1986) defined self-concept as an integrated system of self-schemas, the recent literature views self-concept from a multidimensional perspective (Sirgy \& $\mathrm{Su}, 2000$ ). In the light of this perspective, four aspects of self-concept are usually used to explain consumer behavior. These are the actual self, ideal self, social and ideal social self-concept (Sirgy \& Su; 2000). The actual self and ideal self dimensions are the most empirically tested dimensions (Deloizer \& Tillman, 1972; Dolich, 1969; Landon, 1971).

According to the self-congruity theory, there are two methods of measuring selfimage congruity (Sirgy et al. 1997). The first method is using adjectives. Sirgy has called this commonly used method in consumer behavior literature as the traditional method, which is the mostly accepted and empirically tested method. The new method proposed by Sirgy et al, (1997) based on the analysis of the shortcomings of the traditional method for measuring the self-congruity is the direct method which assumes that self-congruity is a holistic, gestalt like perception. This new method of measuring self-congruity is described below:

Take a moment to think about that destination. Think about the kind of person who typically visits that destination. Imagine the tourists in your mind and then describe this person using one or more personal adjectives, such as, classy, poor, stylish, masculine, and friendly or whatever adjectives you can use the typical visitor of that destination. Once you have done this, indicate your agreement or disagreement to the following statements.

"The image of this destination is consistent with how I see myself" (to measure actual self-congruity)

"The image of this destination is consistent with how I like to see myself" (to measure ideal self-congruity)

Likert type rating scale with this actual and ideal self congruity statements, directly measures the respondents' congruity scores. A review of the literature (Chon, 1992; Kastenholz, 2004; Litvin \& Goh, 2002; 2003; Sirgy \& Su, 2000) suggests that there is a glaring lack of studies on this topic in tourism. In tourism literature the most empirically tested dimensions are actual and ideal self-concept dimensions as in consumer behavior 
literature and also there is the same discussion about measurement of self concept. Chon's (1992) study is a pioneering work which has successfully applied the selfcongruity theory to tourism. According to this study, tourist satisfaction is significantly correlated with actual and ideal self image and the destination's user image. Another importance of this study is the different methods designed for testing the self image congruity. Chon (1992) used straightforward, easily applied questions different from the traditional method in self-concept literature using multiple adjectives for testing the image components. Chon's method is similar to the new method proposed by Sirgy et al. (1997).

Sirgy \& Su (2000) describe an integrative model of destination image, selfcongruity and travel behavior. According to their integrative model; travel behavior is proposed to be influenced significantly by both self-congruity and functional congruity. The symbolic attributes of a destination, in a way the personal images of a product are distinguished from functional or utilitarian attributes in terms of tangible costs and benefits such as quality, price and performance (Sirgy, 1982; Sirgy et al.1997). Personal images of a product reflect the stereotype of the generalized users of that product while self-congruity is defined as the match between product user image and the user's selfconcept (Johar \& Sirgy, 1991). The basic proposition is that travel behavior is affected by self-congruity. That is, the greater the match between the destination visitor image and the tourist's self-concept, the more likely that this tourist will be motivated to visit that destination.

The few empirical studies on this topic in the tourism literature do not sufficiently explain the effect on self-congruity on travel behavior (Chon, 1992; Kastenholz, 2004; Litvin \& Goh, 2002; 2003; Sirgy \& Su, 2000). After Chon's study on self-congruity and satisfaction using direct method of measuring the actual and ideal self-congruity, Litvin \& Goh (2002) used both direct and traditional methods by employing Malhotra (1981)'s scale in order to compare between these two methods in a pre-trip environment. According to the results of this study, Chon's \& Malhotra's methods yield different results, raising the question "if it is a valid tourism theory" especially on a pretrip behavior. However, Kastenholz (2004) by using Malholtra's method also shows the applicability of the self concept theory in the context of a rural destination. It is then considered that the question about traditional and direct measurement methods validity in tourism marketing needs further research.

Another important issue is the moderating variables in this relationship. In Sirgy \& Su's (2000) proposed model, the relationship between self-congruity and travel behavior is affected by such moderator variables as knowledge, prior experience, involvement and time pressure. They argue that those tourists with less knowledge will rely on evaluations of more simplistic cues like destination visitor image. In the case of experience, the basic assumption is that tourists with less experience will be more affected by the self-congruity. In other words the effect of self-congruity on travel behavior is likely to be greater for tourists with less experience. After the theoretical study of Sirgy \& Su (2000), a recent study empirically tests the relationship between self-congruity and destination choice and the moderating effect of experience and involvement in this relationship. According to the results of this study, supporting previous literature, with the effect of experience, self-congruity loses its explanatory power on destination choice. Accordingly, for experienced tourists, self-congruity loses its explanatory power on the intention to visit that destination (Beerli, et al. 2007). 
However, as this is the first and only study that empirically tested the moderator effects in this relationship by using a modified Malhotra's scale to measure self-congruity, there is still a need to test these relationships with moderating variables in different contexts and destinations by different measuring methods like direct method. This study considers two dimensions of self-concept as the actual and the ideal self-concept as they are the most empirically tested aspects in tourism literature where actual self refers to how a person perceives him/herself; ideal self refers to how a person would like to perceive him/herself and measures these dimensions by using the direct method. The hypotheses considered are;

$H_{1}$ : As the prior experience increases, the impact of actual self-congruity on intention to visit that destination decreases.

$\mathrm{H}_{2}$ : As the prior experience increases, the impact of ideal self-congruity on intention to visit that destination decreases.

\section{Method}

\subsection{Sample Design and Data Collection}

The structured online questionnaire, based on a review of the self-concept literature in consumer behavior and tourism, was placed on the web site, "www.gototurkey.com.uk" in cooperation with the Turkish Ministry of Culture and Tourism. A total of 789 questionnaires were completed. Of those respondents who stated the reason for visiting as leisure were considered as the target respondent; accordingly 141 questionnaires were eliminated because of stating the visiting purpose as business. A total of 648 valid questionnaires remained for analysis.

\subsection{Measurement of Variables}

(a) Self-image destination image congruity: Self-congruity is directly measured by using a five point Likert scale based on existing literature (Sirgy et.al, 1997; Sirgy \& $\mathrm{Su}, 2000)$. An instruction is given to the respondents before obtaining self congruity score. After having heard the instructions to measure actual self-congruity and ideal self-congruity, they were asked to rate their level of agreement to the two statements where $1=$ strongly disagree $5=$ strongly agree. The actual and ideal self-congruity data gathered from the respondents was categorized as low and high self-congruity groups according to the midpoint.

(b) Intention: To measure this variable respondents were asked to indicate the level of their intention to visit Turkey over the next two years for vacation purposes on a scale where $1=$ very likely to visit $10=$ do not intend to visit.

(c) Past experience and number of visits: Respondents were asked if they have visited Turkey before and mention the number of visits from the repeat visitors. The tourists' prior experience was classified as non visitors, first time visitors and repeat visitors according to their number of visits. This classification is done according to the tourism literature related to destination image and prior product knowledge stating that image differs according to the past experience of the tourists (Baloğlu, 2001; Fakeye \& Crompton, 1991)

(d) Demographic Characteristics: These variables refer to gender, age, and level of education, marital status, and income. 


\section{Analysis of Results}

The respondents consisted of 47.6 per cent male and 52.4 per cent female subjects. The majority of the respondents are in 31-45 (32.0 per cent) and in 46-49 (40.2 per cent) age groups. 32.4 per cent had a secondary level education, while approximately 46 per cent had a university education (undergraduate and post graduate). Majority of respondents are married with children ( 42.3 per cent). Majority of the respondents have $20 \mathrm{k}-40 \mathrm{k} £$ ( 38.4 per cent) yearly household income. The prior experience of the tourists' as it is categorized as non visitor, first time visitor, repeat visitor distributed as 18.1, 26.1, and 55.9 per cent, respectively. Table 1 presents details on the demographic profiles of the respondents.

Table 1: Dem ographic Characteristics of the Respondents

\begin{tabular}{|c|c|c|}
\hline Variable & Frequency & Percentage \\
\hline \multicolumn{3}{|l|}{ Gender } \\
\hline Male & 300 & 47.6 \\
\hline Female & 339 & 52.4 \\
\hline \multicolumn{3}{|l|}{ Age } \\
\hline $0-18$ & 5 & 0.8 \\
\hline $19-30$ & 96 & 14.8 \\
\hline $31-45$ & 207 & 32.0 \\
\hline $46-59$ & 260 & 40.2 \\
\hline 60 and over & 79 & 12.2 \\
\hline \multicolumn{3}{|l|}{ Education level } \\
\hline Gsce $O$ & 204 & 32.4 \\
\hline Gsce A & 135 & 21.5 \\
\hline Undergraduate & 104 & 16.5 \\
\hline Postgraduate & 186 & 29.6 \\
\hline \multicolumn{3}{|l|}{ M arital status } \\
\hline Single & 179 & 27.9 \\
\hline Married with children & 271 & 42.3 \\
\hline Married with out children & 112 & 17.5 \\
\hline \multirow{2}{*}{\multicolumn{3}{|c|}{ Income $(f)$}} \\
\hline & & \\
\hline $0-10 \mathrm{k}$ & 35 & 6.7 \\
\hline $10 \mathrm{k}-20 \mathrm{k}$ & 78 & 14.9 \\
\hline $20 \mathrm{k}-40 \mathrm{k}$ & 201 & 38.4 \\
\hline $40 \mathrm{k}-60 \mathrm{k}$ & 117 & 22.4 \\
\hline $60 \mathrm{k}$ over & 92 & 17.6 \\
\hline \multicolumn{3}{|l|}{ Living together } \\
\hline Alone & 49 & 12.3 \\
\hline $2-3$ & 242 & 61.0 \\
\hline $4-5$ & 79 & 19.9 \\
\hline 6 or $\mathrm{m}$ ore & 27 & 6.8 \\
\hline \multicolumn{3}{|l|}{ The way to travel } \\
\hline Package tour & 232 & 44.9 \\
\hline Independently & 285 & 55.1 \\
\hline \multicolumn{3}{|l|}{ Prior experience } \\
\hline Non-visitor & 117 & 18.1 \\
\hline First time visitor & 169 & 26.1 \\
\hline Repeat visitor & 362 & 55.9 \\
\hline
\end{tabular}

In order to determine the effect of prior experience as a moderator on the effect of self-congruity on intention to visit Turkey, analysis of variance (ANOVA) is employed. To test the first hypotheses, concerning the actual self-congruity, interaction effect was involved in ANOVA model by using intention to visit as the dependent and the actual self-congruity level as the independent variable. 
M. M. Üner - C. Armutlu - E. Güçer 5/4 (2013) 6-19

T able 2:

Means and Standard Deviations of Intention According to Actual Self-Congruity and Prior Experience

\begin{tabular}{|c|c|c|c|c|}
\hline \multicolumn{2}{|c|}{$\begin{array}{l}\text { Actual Self } \\
\text { Congruity }\end{array}$} & \multicolumn{3}{|c|}{ Prior Experience } \\
\hline & mean & 3.16 & 3.77 & 2.79 \\
\hline \multirow{3}{*}{ Low } & sd. & 2.64 & 2.40 & 2.49 \\
\hline & $\mathrm{n}$ & 64 & 94 & 165 \\
\hline & mean & 2.8 & 2.9 & 2.40 \\
\hline \multirow[t]{2}{*}{$\mathrm{High}$} & sd. & 1.61 & 1.92 & 2.11 \\
\hline & $\mathrm{n}$ & 53 & 75 & 197 \\
\hline
\end{tabular}

Table 2 provides the mean and standard deviation results of the tourists' intention, categorized as low and high actual self-congruity and prior experiences for non-visitors, first-time visitors and repeat visitors.

T a ble 3:

Effect of Actual Self Congruity and Experience on Intention

$\begin{array}{cccccc} & \begin{array}{c}\text { Sum of } \\ \text { Squares }\end{array} & \begin{array}{c}\text { Degrees of } \\ \text { Freedom }\end{array} & \begin{array}{c}\text { Mean } \\ \text { Squares }\end{array} & \text { F } & \text { p-value } \\ \text { Actual-Self Congruity } & 107.88 & 1 & 107.88 & 22.28 & .000 \\ \text { Experience } & 34.72 & 2 & 17.36 & 3.58 & .028 \\ \text { Actual-Self Congruity } & 26.39 & 2 & 13.19 & 2.72 & .066 \\ \quad \begin{aligned} \text { Experience } \\ \text { Error }\end{aligned} & 3150.51 & 642 & 4.84 & & \end{array}$

\section{Interaction between prior experience and actual self-congruity}

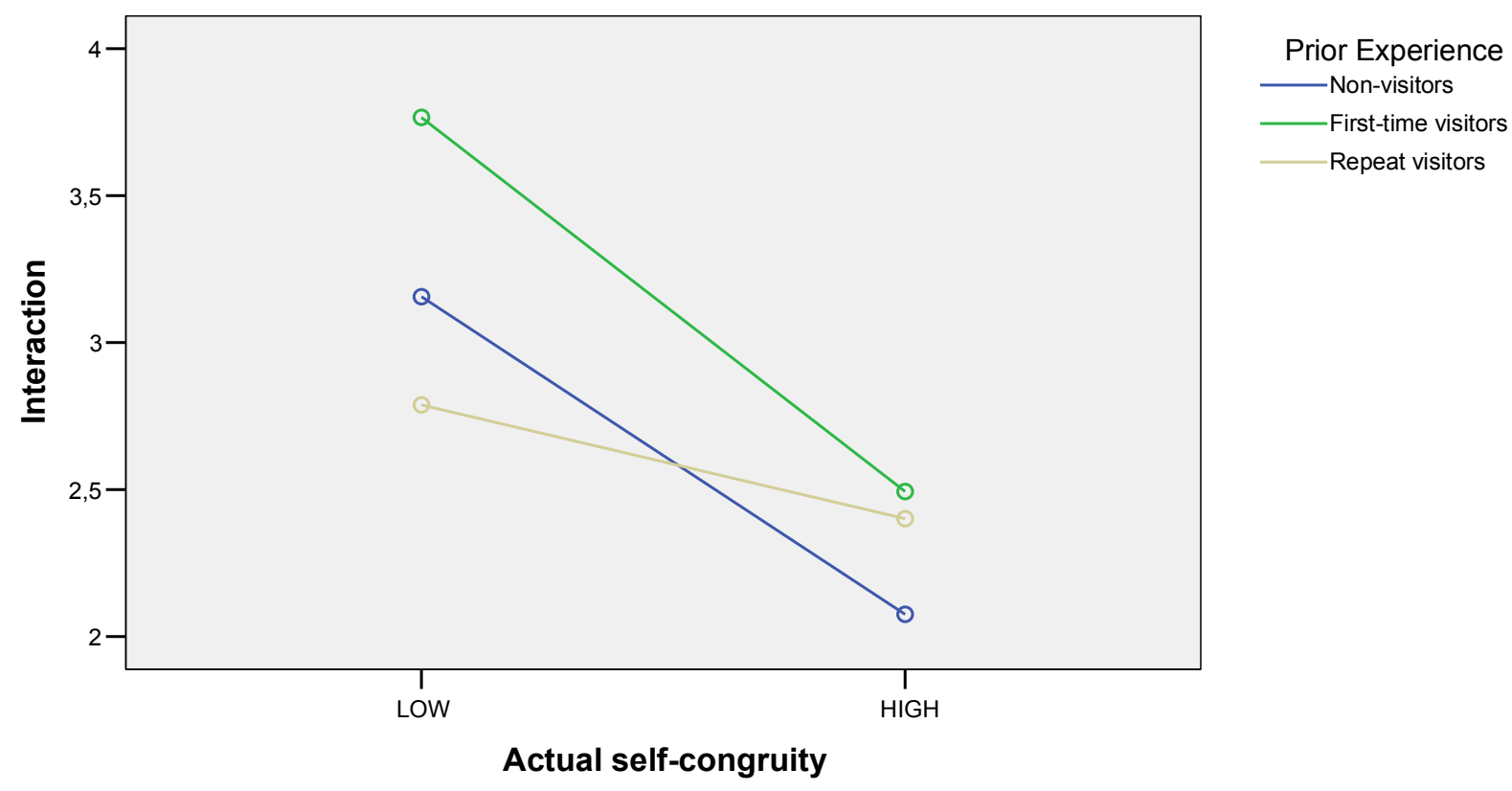


The main effects of actual self congruity and prior experience on intention are provided in Table 3. Both actual self congruity and experience levels have a significant effect on the tourist's intention to visit Turkey. The tourists with high actual selfcongruity have higher intention then the tourists with low actual self-congruity regardless of prior experience levels. On the other hand experience has a significant effect on the intentions of tourists. As the non visitors' intention is higher than the other groups and the first time visitors have the lowest intention.

According to the results of a two way ANOVA, the interaction effect of actual selfcongruity and prior experience on intention to visit is significant at 0.10 level. This implies that the impact of actual self-congruity on intention differs according to various prior experience levels of the tourists. This result suggests that prior experience moderates the relationship between actual self-congruity and intention to visit that destination. Accordingly, $\mathrm{H} 1$ is supported. The relationship between actual selfcongruity and intention to visit Turkey differs according to the prior experience levels as it is shown in Figure1. The impact of actual self-congruity on intention for the nonvisitors and the first-time visitors are similar as their lines (Figure 1) are relatively close to parallel. This suggests that actual self-congruity effect does not lose its explanatory power for the first-time visitors, still having an impact on the tourists' intention to visit Turkey. On the other hand, for the repeat visitors, this relationship is different from the other groups as it is shown in Figure1, implying an interaction effect. For the repeat visitors' actual self-congruity does not have a significant effect $(\mathrm{t}=1.599, \mathrm{p}>0.1)$ on the intention to visit. Thus it can be concluded that for the repeat visitors, actual selfcongruity effect loses its power on the intention to visit Turkey.

The second hypothesis proposed above referred to the moderating role of prior experience on the impact of ideal self-congruity on intention. In order to test this hypothesis, a two way ANOVA was conducted. While the main effects of ideal selfcongruity and prior experience on intention have a significant difference on tourist's intention to visit Turkey, the interaction effect of ideal self-congruity and prior experience on intention to visit is not significant as it seen in Table $5(\mathrm{~F}=0.600, \mathrm{p}>0.1)$ which means that there is no interaction effect of ideal self-congruity and prior experience on the intention of the tourists. However, there are changes on the effect of ideal self-congruity on intention; this suggests that the effect of ideal self-congruity on intention does not significantly differ according to the prior experience of the tourists. Different from the results of the actual self-congruity, for the repeat visitors the impact of ideal self-congruity does not lose its explanatory power on intention, still having a significant effect $(\mathrm{t}=1.654, \mathrm{p}<0.1)$ on the intention to visit

T a b le 4 :

Means and Standard Deviations of Intention According to Ideal Self-Congruity and Prior Experience

\begin{tabular}{|c|c|c|c|c|}
\hline L ow & $\begin{array}{l}\text { elf } \\
\text { ity } \\
\text { m ean } \\
\text { sd. } \\
\mathrm{n}\end{array}$ & $\begin{array}{c}\text { Non Visitors } \\
3.08 \\
2.11 \\
62\end{array}$ & $\begin{array}{c}\text { Prior Experience } \\
\text { First-time Visitors } \\
3.51 \\
2.50 \\
97\end{array}$ & $\begin{array}{c}\text { Repeat } \mathbf{V} \text { isitors } \\
2.79 \\
2.51 \\
159\end{array}$ \\
\hline $\mathrm{H}$ ig h & $\begin{array}{l}\mathrm{m} \text { ea } \mathrm{n} \\
\mathrm{sd} \text {. } \\
\mathrm{n}\end{array}$ & $\begin{array}{r}2.20 \\
1.64 \\
55\end{array}$ & $\begin{array}{r}2.82 \\
1.91 \\
71\end{array}$ & $\begin{array}{l}2.39 \\
2.10 \\
202\end{array}$ \\
\hline
\end{tabular}


T a ble 5:

Effect of Ideal Self Congruity and Experience on Intention

$\begin{array}{cccccc} & \begin{array}{c}\text { Sum of } \\ \text { Squares }\end{array} & \begin{array}{c}\text { Degrees of } \\ \text { Freedom }\end{array} & \begin{array}{c}\text { Mean } \\ \text { Squares }\end{array} & \text { F } & \text { p-value } \\ \text { A ctual-Self Congruity } & 55.500 & 1 & 55.500 & 11.274 & .01 \\ \text { Experience } & 38.011 & 2 & 19.005 & 3.861 & .022 \\ \text { Actual-Self Congruity } & 5.908 & 2 & 2.954 & .600 & .549 \\ \begin{array}{c}\text { X } \\ \text { Experience } \\ \text { Error }\end{array} & 3150.519 & 642 & 4.923 & \end{array}$

\section{Discussion and Conclusion}

This study examines the moderator effect of prior experiences of tourists' in the relationship between self-congruity and intention to visit Turkey. Accordingly, the effects of actual and ideal self-congruity on the intention of the tourists' are analyzed based on varying levels of prior experiences. Limited studies in tourism about selfcongruity discusses the role of prior experience in the relationship between selfcongruity and intention to visit a destination (Beerli et al., 2007; Sirgy and Su, 2000). The only empirical study testing that relation indicates that experience reduces both actual and ideal self congruity effect (Beerli et al, 2007). The findings of the present study mostly support mentioned relationship but identifies two important issues. First, prior experience has a moderator effect in the relationship between actual selfcongruity and intention to visit Turkey but in the case of ideal self-congruity, prior experience didn't moderate this relationship. In other words, when the actual selfcongruity loses its power on intention for the repeat visitors, ideal self congruity does not lose its significance. Second, this study different from other studies, categorizes the past experience as non-visitors, first-time visitors and repeat visitors. Accordingly, selfcongruity effect is significant for both non-visitors and first-time visitors. In other words, the relationship between self-congruity and intention does not vary between nonvisitors and first-time visitors. This categorization make it possible to reach that result, as if it is categorized as experienced and non-experienced, the first-time visitors would be evaluated as experienced visitors and a decrease on the self-congruity effect would be expected. However, according to this study, self-congruity still has an effect on intention for the first-time visitor. Although these results are similar with the previous findings the above mentioned issues raise new questions. Why actual self congruity does not lose its impact on intention for the first time visitors? Why doesn't prior experience moderate ideal self congruity? What can be the causes of these results?

According to the literature, self-congruity is a simplistic cue that has an effect on tourist behavior; thus tourist with no experience would rely on this cue on their decisions The basic assumption underlying this suggestion is the increase in functional congruity's effect with experience (Beerli et a l., 2007; Sirgy \& Su, 2000). Although these suggestions, without including the effect of functional congruity, have been empirically tested and supported by the previous findings (Beerli et al,, 2007), the findings of this present study for first time visitors makes it difficult to say that selfcongruity effect loses its power on intention with experience. And also the assumption 
that functional congruity will be more effective than self-congruity on the intention still remains to be tested. On the other hand the result for repeat visitors' indicates that selfcongruity does not have an impact on the tourists' intention to visit Turkey which confirms the previous studies findings and suggestions. However it is still difficult to state that it is because the symbolic aspect loses its power and functional congruity is more dominant in the repeated visitors' intention. Therefore further research is needed to provide definitive results.

The present paper uses direct measurement method as Sirgy et.al (2007) suggests that this method overcomes the problem of others. But a recent study findings show that different measurement methods reveal different results (Boksberger, Dolnicar, Laesser \& Randle, 2011). It is to say that in tourism empirical findings on that research area are still few and confusing. Future research may focus on other measurement methods to test the same model in order to generalize the findings. And also extended models may be developed to better explain this relationship with new intervening variables.

Future research should also consider that, there can be a relationship between prior experience and the self-congruity that is not discussed before in the literature. In consumer behavior literature related to self-congruity, one of the moderating variables discussed is the ownership (Barone, Shimp and Sprott, 1999). The meanings of products are transformed to consumers through the process of ownership and they become part of the "extended self". So for an owned product, consumers will perceive more congruency between a product's image and their self-concept. In a way the ownership has a positive effect on self-congruity evaluations (Baron et.al., 1999). On the other hand, in a study in tourism literature for the experienced tourists stating that respondents didn't assign a great deal of importance to the information having symbolic meaning, mention that meaning has gone for these respondents as they can no longer recognize the importance it had for them prior to their purchase due to the fact that the object (vacation) is now in fact the part of the individual's life (Cho \& Kestetter, 2004). This result supports the idea that the ownership effect for the products and experience effect for tourism products can be seen as similar. So the ownership effect for the products can give new insight to the relationship between the experience and the destination image and self-image congruity. This interesting view can direct future research in order to explain the role of prior experience in detail. On the other hand the relationship between prior experience and repurchase behavior can be investigated. As previous studies suggest that experience has a direct effect on destination image; the more familiar a destination becomes, the more positive becomes its image (Baloglu, \& McCleary 1999; Echtner \& Richie, 1993; Fakeye, \& Crompton 1991; Milman \& Pizam, 1995) and some studies indicate that the number of past visits positively affects repurchase that destination (George \& George, 2004; Kozak 2001).

The theoretical view of self-congruity implies that managers of destination marketing organizations should consider the symbolic attributes of the destination as well as the functional attributes as it is important at designing promotional messages in order to create desirable images of a destination for target segments. However, these messages should be differentiated according to the specific segments; our study shows another significant issue for segmentation to be considered as the experience. In market segmentation, the experience should be another important criterion as the impact of symbolic features of a destination differs for the repeat visitors. So by taking this issue in to consideration, managers should create their promotional messages according to the 
visitors especially. For example for the non-visitors, the messages should be focused on symbolic attributes.

These findings suggest several possibilities for future research. These can be summarized as: (1) reexamine the moderating effect of prior experience on the relationship between self-congruity and intention to visit a destination; (2) examine other moderator variables on the self-congruity effect; and (4) examine the effects of other self-congruity dimensions such as social and ideal social self-congruity and different dependent variables like choice, preferences, satisfaction and loyalty. It is hoped the present study serves as a solid foundation for such future inquiries.

\section{References}

Baloglu, Ş. (2001) Image variations of Turkey by familiarity index: informational and experiential dimensions. Journal of Hospitality \& Tourism Research, 22 (3): 211- 224.

Baloglu, S. \& Brinberg, D. (1997) Affective images of tourism destinations. Journal of Travel Research, 35 (4):11-15.

Baloglu, S. \& Mangaloglu M. (2001) Tourism destination images of Turkey, Egypt, Greece, and Italy as perceived by us-based tour operators and travel agents. Tourism Management, 22:1-9.

Baloglu, S. \& McCleary (1999). U.S. international travelers' images of four Mediterranean destinations: a comparison of visitors and non-visitors. Journal of Travel Research; 38: 144-152.

Barone, M,J., Shimp, T.A. \& Sprott, D.E. (1999) Product ownership as a moderator of self-congruity effects. Marketing Letters 10 (1): 75-85.

Beerli, A, Meneses,G.D. \& Gil, S.M. (2007) Self-congruity and destination choice. Annals of Tourism Research, 34(3): 571-587.

Belk, R.W. (1988) Possessions and the extended self. Journal of Consumer Research, 15: $139-168$.

Boksberger, P. ,Dolnicar, S, Laesser, C. \& Randle,M. (2001) Self-congruity theory: To what extent does it hold in tourism? Journal of Travel Research, 50(4):454-464.

Bramwell, B. \& Rawding, L.(1996) Tourism marketing images of industrial cities. Annals of Tourism, 23: 201-221.

Chaudhary, M.(2000) India's image as tourist destination-a perspective of foreign tourists. Tourism Management, 21: 293-297.

Chen, J.S.(2001) A case study of Korean outbound travelers' destination images by using correspondence analysis. Tourism Management, 22: 345-350.

Chen, J. S. \& Hsu, C. H. C. (2000) Measurement of Korean tourists' perceived images of overseas destinations. Journal of Travel Research,38: 411-416.

Chen, P. J. \& Kerstetter, D. L. (1999) International students' image of rural Pennsylvania as a travel destination. Journal of Travel Research, 37: 256-266. 
M. M. Üner - C. Armutlu - E. Güçer 5/4 (2013) 6-19

Cho,M., \& Kerstetter,D.L. (2004) The Influence of sign value on travel-related. Leisure Sciences, $26: 19-34$.

Chon,K.S.(1992) Self-image/destination image congruity. Annals of Tourism Research, 19(2): 360-363.

Dann, G. M. S. (1996) Tourists' images of a destination-an alternative analysis. Recent Advances in Tourism Marketing Research, 5 (1/2): 41-55.

Delozier, M,W. \& Tillman, R.(1972) Self-image concepts- can they be used to design marketing programs? Southern Journal of Business, 7(1): 9-15.

Dolich, I. J. (1969) Congruence relationships between self images and product brands. Journal of Marketing Research, 6: 80-84.

Echtner C.M. \& Richie J.R.B. (1993) The measurement of destination image: an empirical assessment. Journal of Travel Research, 31(spring): 3-13.

Fakeye, P. C. \& Crompton, J.L.(1991) Image differences between prospective, first time and repeat visitors to the lower Rio Grande Valley. Journal of Travel Research 30(2): 10-16.

Fridgen, J.D. (1987) Use of cognitive maps to determine perceived tourism regions, Leisure Sciences, 9: 101-117.

Gartner, W. C. (1993) Image formation process. Journal of Travel and Tourism Marketing 2 (2/3): 191-215.

George, B.P. \& George, B.P. (2004) Past visits and the intention to revisit a destination: place attachment as the mediator and the novelty seeking as the moderator. Journal of Tourism Studies, 13(2): 51-66.

Graeff, T. R.(1996) Using promotional messages to manage the effects of brand and self-image on brand evaluations. Journal of Consumer Marketing, 13(3): 4-18.

Grubb, E. \& Grathwohl, H. (1967) Consumer self-concept, symbolism and market behavior, a theoretical approach. Journal of Marketing, 31:22-27.

Grubb, E. \& Hupp, G. (1968) Perception of self, generalized stereotypes and brand selection. Journal of Marketing Research, 5: 58-63.

Hackley, C. (2003) Doing Research Projects In Marketing Management And Consumer Research, Routledge:, London.

Hirschman, E.C. \& Holbrook, M.B. (1982) The experiential aspects of consumer behavior: consumer fantasies, feelings, and fun. Journal of Consumer Research, 9: $132-140$.

Hsu C. H .C., Wolfe K. \& Kang K.S.(2004) Image assessment for a destination with limited comparative advantages. Tourism Management, 25:121-126.

Hung, K.\& Petrick, J.F. (2012) Testing the effects of congruity, travel constraints, and self-efficacy on travel intentions: An alternative deision making model. Tourism Management 33:855-867.

Johar, J. S. \& Sirgy, J. M. (1991) Value expressive versus utilitarian appeals: when and why use which appeal. Journal of Advertising , 20 (3):23-34. 
M. M. Üner - C. Armutlu - E. Güçer 5/4 (2013) 6-19

Kassarjian H.H. (1971) Personality and consumer behavior: A review. Journal of Marketing Research, 8:409-418.

Kastenholz, E. (2004) Assessment and role of destination self-congruity. Annals of Tourism Research, 31: 719-723.

Kozak, M. (2001) Repeaters' behavior at two distinct destinations. Annals of Tourism Research, 28(3): 784-807.

Landon, E. L. (1974) Self-concept, ideal self-concept, and consumer purchase intentions. Journal of Consumer Research, 1: 44-51.

Lee, D.H. (1990) Symbolic interactionism: some implications for consumer: selfconcept and product symbolism research. Advances in Consumer Research, 17:386-393.

Levy, S.J. (1959) Symbols for sale. Harvard Business Review; 37(4): 117-124.

Litvin, S.W. \& Goh, H. (2002) Self-image congruity: a valid tourism theory? Tourism Management, 23: 81-83.

Litvin, S. W. \& Goh, H. (2003) Individualism/collectivism as a moderating factor to the self-image congruity concept. Journal of Vacation Marketing, 10(1):23 - 32.

Malhotra, N. K. (1981)A scale to measure self-concepts, person concepts and product concepts. Journal of Marketing Research, 18:456-464.

Markus, H. \& Nurius, P. (1986) Possible selves. American Psychologist, 41 (9):954969.

Milman A. \& Pizam A. (1995)The role of awareness and familiarity with a destination: the Central Florida case. Journal of Travel Research, 33(3): 21-27.

Morgan, A, J. (1993) The evolving self in consumer behavior: exploring possible selves. Advances in Consumer Research,20: 429-432.

Munson, J, M. \& Spivey, A.W. (1980)Assessing self-concept. Advances in Consumer Research , 7:598-603.

Onkvisit, S. \& Shaw, J. (1987) Self-concept and image congruence: some research and managerial implications. Journal of Consumer Marketing, 4(1): 13-23.

Reed II, A. (2002). Social identity as a useful perspective for self-concept based consumer research. Psychology and Marketing 19(3):235-266.

Sharaiha, Y. M. \& Collins, P. Q. (1992) Marketing Jordan as a tourist destination. Tourism Management, March: 64-70.

Sirgy, M. J. (1982) Self-concept in consumer behavior: a critical review. Journal of Consumer Research, 9: 287-299.

Sirgy, M. J. (1985) Using self-congruity and ideal congruity to predict purchase motivation. Journal of Business Research,13: 195-206.

Sirgy, M. J., Grewal, D, Mangleburg, T. F., Park K., Chon, J.B., Caliborne, C.B., Johar, J.S. \& Berkman H. (1997) Assessing the predictive validity of two methods of measuring self-image congruence. Journal of the Academy of Marketing Science, 25 (3): 229-241. 
M. M. Üner - C. Armutlu - E. Güçer 5/4 (2013) 6-19

Sirgy, M, J., Su C.(2000) Destination image, self-congruity, and travel behavior: toward an integrative model. Journal of Travel Research ,39: 340-352.

Solomon, M. R. (1983) The role of products as social stimuli: a symbolic interactionism perspective. Journal of Consumer Research, 10, 319-329.

Usakl1, A. \& Baloglu, S. (2011) Brand personality of tourist destinations: An application of self-congruity theory. Torusim Management 32:114-127.

Wattanasuwan, K. (2005) The self and symbolic consumption. The Journal of American Academy of Business., March, 179-184. 